\section{Historical Depiction Of Great Person \\ "Tamerlane" In The Poem Of Edgar Allan Poe}

Rasulova Sokhiba Ulugbekovna

Teacher Of The Department English Language And

Literature, Samarkand State Institute Of Foreign Languages

Samarkand, Uzbekistan

\begin{abstract}
G OPEn ACCESS
The American Journal of Social Science And Education Innovations JULY 2020

Page No.: 123-128

Volume-II Issue-VII

PUBLISHED: 30 JULY 2020 www.usajournalshub.com/inde x.php/tajssei

Copyright: Original content from this work may be used under the terms of the Creative Commons Attribution 4.0 licence.
\end{abstract}

\title{
Abstract
}

In the article, the author reflects on the work of the famous American writer Edgar Poe, his rich in romantic emotions. The author's poem "Tamerlan" and its translation into Uzbek are analyzed.

Keywords: Romance, poem, translation, novella, fantasy adventure events.

\section{Introduction}

The work of Edgar Allan Poe (Edgar Alan Poe, 1809-1849) occupies an important place in the literature of nineteenth-century American and European romanticism. The writer was one of the creators of the development of his contemporaries Fennimore Cooper, Natalie Hawthorne, "Henry Longfellow. The future poet and novelist Edgar Allan Poe was born on January 19, 1809 in Boston, in a family of theater actors. The boy was adopted by the son of a wealthy merchant named John Allan from Virginia. Edgar spent his childhood in England with his captive parents. He was educated in prestigious schools there, for the first time read the works of Chooser and Shakespeare, studied English diligently. When 
the Allan returned to the United States in 1820, the young Edgar was sent to college in Richmond. Latin and ancient Greco-Roman literature was taught in depth at the college. There he became acquainted with the poetry of Virgil and Ovid, especially the English Romantic poetry of his predecessors, R. South, W. Wordsworth, S. Coleridge, Byron, and Shelley, and began to write in their own way. After graduating from college, Edgar Poe continued his studies at the University of Virginia. Unfortunately, his student days and carefree life did not last long. In 1826 he had an argument with his father, John Allan, who left the university and went to Boston. Here he spent all his money with the help of his friends, published a collection of his first book of poetry, Tamerlane and Other Poems (1827). The author notes in the preface of the book that the poems and verses in the collection were the first exercises he created during his childhood and adolescence, in which his youthful dreams and passionate emotions were sung in a mood imitating Byron. It is the main work in the collection, which was written under the direct influence of Byron. The protagonist of the work is the great master, the famous commander in the East and the West, the ruler Amir Temur, whose thoughts of old age are written in the imagination of a young romantic poet. The old ruler tells a passing priest about his life, his victorious journey, his human feelings, and he regrets that all this is happening in the past:

Kind solace in a dying hour!

Such, father, is not (now) my theme:

I will not madly think that power

Of earth may shrive me of the sin

Unearthly pride hath revell'd in -

I have no time to dote or dream:

You call it hope - that fire of fire!

It is but agony of desire -

If I can hope (O God! I can)

Its fount is holier - more divine -

I would not call thee fool, old man,

But such is not a gift of thine.

(Translated from Russian by Miraziz Azam) 
Edgar Allan Poe's poem "Tamerlane" is similar in content and logic to Byron's epics, which are included in the "Poems of the East", as well as "The Room Dedicated to Napoleon." The image of romantic feelings, enthusiasm and mental anguish in them is very close to each other. Even Edgar Poe, in his poem, was determined to apply the iambus temple to the weight of the four constant poems in Byron's poetry.

\section{The Main Part}

Young Edgar, who has no residence in Boston and no definite training, is drafted into the military to seek asylum. After a year of service, he wrote a letter apologizing to his father, Allan, for his dissatisfaction with his military life. At the urging of his captive wife, Mrs. Allan, Edgar compensates and saves him from military service. Edgar Poe comes to Baltimore and is busy with creativity again. He reworks the poem "Tamerlane," which is included in his first book. He writes his second poem, Al-Aaraaf, in a romantic spirit. In 1829, the poet published his second collection of poetry, Al-Aaraaf; Tamerlan and other minor poems (Al Aaraaf, Tamerlan and minor Poems, 1829). The poem "Al-Aaraaf" in the collection is written in sync with John Miltoni's epic "Lost Paradise" ("Raradise Lost", 1667), in which the poet discovered a magical part of the star "Al-Aaaraf", discovered by astronomer Taxo-de-Brage. tells the story of how he appeared for a few minutes and then disappeared. The divine power and heavenly development of this star, which appeared in the sky and then disappeared from view, was absorbed into the content of the epic as a result of the poet's philosophical observations.

Meanwhile, the writer, who entered the military academy to get a higher education at the urging of his stepfather, could not bear the strict discipline there, left the academy and fought with his father again.

The years 1831 - 1833 were the most difficult period in Edgar Poe's life, when due to unemployment the young poet began living in Baltimore with his aunt Mrs. Clem and his daughter Little Virginia. Despite the difficulties of life, he continues to create and writes new poems and short stories. The 1833 Saturday Visitor Week in Baltimore announces a competition for the best story and poem. Edgar Poe will also take part in the competition 
with his short stories and win. After his weekly novel, MS. Found in the Bottle, was published weekly, the pen cost the author sometime.Because of the lack of more casual attire, the writer can't even go to the weekly editor John F. Kennedy's lunch in honor of the contest winner. In 1833, the poet's stepfather, John Allan, died. Although he was rich, Edgar Poe did not inherit a single penny. The winner of the competition will be invited to work for Thomas White's Southern Literary Messenger in Richmond. Edgar Poe publishes several of his short stories in the pages of magazines, such as "Morella," "Berenica," and "The Adventures of Gans Pfall." In 1836, the fourteen-year-old daughter of her aunt, Mrs. Clem, moved to New York at the suggestion of the writer T. White, who married a beautiful Virginia, and began to work as editor-in-chief of the Southern Literary Journal. Soon, thanks to his efforts, the magazine's circulation will increase and it will attract the attention of customers. But a salary of five or six dollars a week and a meager penny barely enough to feed his family, a family of three living in a big city for a living.

In 1838, Edgar Allan Poe moved to Philadelphia with his wife and aunt and became editor of the Gentlemen's Magazine. The editorial salary was ten dollars a week. The writer does not shy away from editing as well as artistic creation. His short stories "The Adventures of Arthur Pim" and "Memories of Julia Rodman" will increase the reputation of the magazine, the number of subscribers will increase. In 1841, Edgar Poe was appointed editor of Graham's Magazine, one of the most prestigious magazines. Due to the writer's activism, Edgar Allan Poe's reputation will only grow as soon as the magazine's circulation reaches 40,000 .

The author collected his short stories and in 1841 published a two-volume book entitled "Tales of the Grotesque and Arabesque". The short stories in the collection are depictions of scientific, fiction and adventure events, in which human psychology is skillfully illuminated through a variety of images.

\section{Results And Discussions}

In the spring of 1842 , when he was relieved of his post as editor of the Green Magazine, the unemployed foreign writer was again offered a job at the neglected Saturday Museum. Edgar Poe publishes his famous short story "The Gold Bug" on the cover of the magazine. 
With the publication of this short story, the reputation of the magazine rises. The author gets a hundred dollars pen fee. This was the largest pen fee Edgar Poe had ever received.

But by 1844 , the writer, once again mired in poverty, returned to New York with his family to find a better job, where he made a living by paying a penny for his published works. In January 1945, The Evening Mirror published the author's famous poem, The Raven. The author receives a ten-dollar pen fee for the poem. However, an autographed copy of the poem in 1891 was sold at auction for $\$ 225$.

In 1846, Edgar Allan Poe's last collection of poems, The Raven and Other Poems, was published. Although this collection has been published four times during the poet's lifetime, master publishers and booksellers pay very little for the author. In January 1847, the author's wife, the beautiful Virginia, died of a serious illness at the age of twenty-five. After this loss, the writer becomes depressed and humane, putting lipstick on the wine. But Edgar Poe doesn't stop creating even in this situation. In the last years of his life, he completed his best poems, such as Ulalume, The Bells, Annabel Lee, and his philosophical epic Eureka. However, the hardships of life and the pain of separation had left the writer mentally ill. On October 7, 1849, the writer died at a hospital in Baltimore.

\section{Conclusions}

Edgar Allan Poe's poems and verses, which are full of romantic sentiments, and his novels, rich in fantasy and adventure, are among the best works of world literature. Uzbek readers also read the author's stories in their native language. His epic "Tamerlane" was translated by poets Miraziz Azam and Fakhriyor and published in the journals "Literature ofworld"and"CultureandArts".

Edgar Allan Poe's poems and verses, imbued with romantic sentiments, are among the best works of world literature, rich in fantasy and adventure stories. Uzbek readers were also able to read the author's stories in their native language. His epic "Tamerlane" was translated by the poet Miraziz Azam and published in the magazine "Literature of world". 


\section{References}

1.Poe E.A. The complete poetical works. Ed. by A.B.Johnson-London: Oxford University. 1919-LX.316 p

2. Po E.A Selected works: B2-x Thomas - M: Art. lit, 1972

3. Po E. "Tamerlane «poem. Translated from the English by Dilshoda Ibragimova. "Student World", 2010.4 th issue.

4. Kholbekov M. The newspaper "Uzbekistan literature and art", 2009. 24th issue

5. Complete collection of poems and poems, trans, and foreword. Valery Bryusov with a critical bibliographic commentary, ed."World Literature", M-L., 1924.

6. Nikolyukin A. 13. The life and work of Edgar Allan Poe. - In the book: Edgar Allan Poe. Complete collection of stories. M., "Science", 1970.

7. Ch. Haincs. Edgar Allan Roy. His writings and influence. New York, 1974.

8. Phillips, Mary E.Edgar Allan Poe: The Man. - Chicago: The John C. Winston Company, 1926.

9. Kovalev Yu.V. Edgar Allan Poe. Novelist and poet, L., 1984;

10. Edgar. Ballads and (fantasies. Translated from English by K. Balmont. M., 1895.

11. Doniyorov, A. K., \& Karimov, N. R. (2020). An Incomparable Book of a Great Scholar. Bulletin Social-Economic and Humanitarian Research, (6), 63-71. 